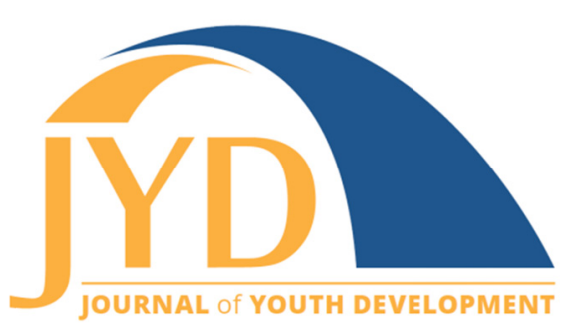

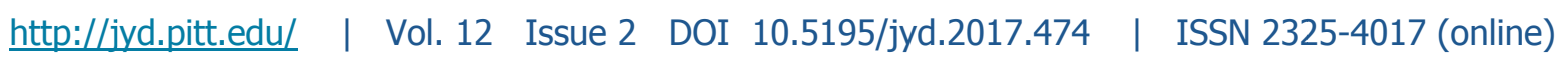

\title{
Fostering Curiosity, Inquiry, and Scientific Thinking in Elementary School Students: Impact of the NE STEM 4U Intervention
}

\author{
Heather D. Leas \\ University of Nebraska Omaha \\ hdleas@unomaha.edu \\ Kari L. Nelson \\ University of Nebraska Omaha \\ karinelson@unomaha.edu \\ Neal Grandgenett \\ University of Nebraska Omaha \\ ngrandgenett@unomaha.edu \\ William E. Tapprich \\ University of Nebraska Omaha \\ wtapprich@unomaha.edu \\ Christine E. Cutucache \\ University of Nebraska Omaha \\ ccutucache@unomaha.edu
}

\begin{abstract}
In this qualitative study, we assessed the impact of the NE STEM $4 U$ intervention on elementary school youth in terms of excitement, curiosity, and STEM concepts. The NE STEM $4 U$ intervention incorporates a problem-based learning theoretical framework in an after-school time, weekly or twice-weekly intervention. We assessed student performance over two academic years of participation in the intervention using the Dimensions of Success observational tool. Ultimately, we link this mentor-led program with increases in curiosity, inquiry, and STEM concept gains. Taken together, these findings support after-school interventions in STEM areas as key encouraging excitement in youth and motivation to pursue a career in a STEM content area.
\end{abstract}

Key words: NE STEM 4U, afterschool, STEM, content knowledge, Dimensions of Success (DoS), outreach

(cc) EY $_{\text {EY }}$ New articles in this journal are licensed under a Creative Commons Attribution 4.0 License. This journal is published by the University Library System, University of Pittsburgh and is cosponsored by the University of Pittsburgh Press. The Journal of Youth Development is the official peer-reviewed publication of the National Association of Extension 4-H Agents and the National AfterSchool Association. 


\section{A Critical Time for STEM Education in After-school Time}

There is a great need to fill the science, technology, engineering, and mathematics (STEM) pipeline in the United States. While youth in the United States continue to rank behind youth in other countries in STEM performance, namely, $24^{\text {th }}$ in science and $39^{\text {th }}$ in mathematic competencies out of 65 countries (Desilver, 2017), the United States also fails to meet the needs of current employers in terms of skilled laborers in STEM areas. Currently, the state of Nebraska reflects these trends. To address these shortcomings, the Omaha, Nebraska Chamber of Commerce seeks to establish the city of Omaha as a "tech hub" by 2020 with an additional 4,000 jobs (Greater Omaha Chamber of Commerce and AIM/Careerlink, 2015). Moreover, Omaha was recently designated as one of the national "STEM Ecosystem" sites by the STEM Funders Network to build community efforts for bringing youth into the STEM pipeline (Teaching Institute for Excellence in STEM, 2016). Such STEM Ecosystem sites coalesce community efforts for that purpose. Synergistically, Nebraskans are committed to providing high-quality training in STEM areas, and feeding the pipeline for long-term economic stability. While these goals of the state and nation are laudable, we continue to face challenges both locally and nationally.

Challenges for building a robust STEM community and workforce include: (a) how to maintain the curiosity by youth to pursue STEM areas of study, (b) how to structure a STEM pipeline that takes youth into careers, and (c) how to retain a talented STEM workforce in Nebraska. In this study, we investigated the first of these challenges through an intervention developed and implemented in the Omaha metropolitan area. Specifically, we created an after-school program called NE STEM 4U, in partnership with several local stakeholders including Omaha Public Schools, Collective for Youth, Beyond School Bells, and local funding agencies, (Cutucache, Luhr, Nelson, Grandgenett, \& Tapprich, 2016) where we deliver problem-based learning lessons in STEM to elementary and middle school students. Problem-based learning (PBL) is a learnercentered method of teaching that engages students in hands-on activities that require them to solve problems, conjecture, experiment, explore, create, and communicate. The goal of PBL is to engage students in the learning process, enhance their critical thinking skills, and boost their long-term retention of material (Chng 2011; Nicholl \& Lou 2012; Salinitri, O'Connell, Garwood, Lehr, \& Abdallah, 2012; Wiznia, Korom, Marzuk, Safdieh, \& Grafstein, 2012;). It has been shown to help students at all levels to more effectively learn complex concepts, particularly in science and mathematics (Avanzato, 2000; Cusick, 2001). 


\section{Impact of the NE STEM 4U Intervention}

The value of PBL is widely recognized, and the use of PBL exercises has increased over the past decade. In the biological sciences, however, this teaching approach has been restricted mostly to graduate-level and professional-level education (Husain, 2011; Imans \& Wilkerson 2011; Klegeris \& Hurren, 2011; Lira \& Lopes, 2011; Okubo et al., 2012). Such an active learning strategy adds to students' abilities, including, for example, the ability to apply the process of science and use quantitative reasoning. Through this program, we have reached out to Omaha youth to enhance their awareness and curiosity about STEM areas.

It is well-documented that youth choose whether or not to pursue careers in STEM fields by eighth grade and choose whether they enjoy STEM content areas by as early as fourth grade (Maltese \& Tai 2010; President's Council of Advisors on Science and Technology, 2010; Tai, Liu, Maltese, \& Fan 2006). The NE STEM 4U program was designed to target youth who are forming their opinions about STEM areas and STEM careers. Our data (and that of others: Schnittka, Evans, Won, \& Drape, 2015; Cutucache, Luhr, Nelson, Grandgenett, \& Tapprich, 2016) show that youth participating in after-school programs like NE STEM 4U demonstrate increased content knowledge, as well as improved problem-solving skills. Youth who participate in out-ofschool time (OST) STEM activities are also more interested in STEM disciplines in college (Dabney et al., 2011). Such interests coupled with learning gains will contribute to career competitiveness for youth that choose to pursue a career in a STEM area. NE STEM 4 U provides a model that can be replicated by other metropolitan universities to increase STEM awareness and curiosity in youth nationwide.

After-school STEM experiences have broad positive impacts on youth development. For example, after-school programs that build upon the school day improve academic performance, attendance rates, social skills, and STEM interest (Carpenter, 2015; Constan \& Spicer, 2015; Lauer et al., 2006; Miller, 2003; Tyler-Wood, Ellison, Lim, \& Periathiruvadi, 2012). Learning gains that result from exposure to after-school STEM at the elementary level also promote youth preparedness for the transition to middle school STEM curricula (Moreno, Tharp, Vogt, Newell, \& Burnett, 2016). Relatedly, after-school programs at various academic levels show potential long-term effects on perceptions of science careers, STEM technical skills, and understanding of such skills in STEM careers (Duran, Höft, Lawson, Medjahed, \& Orady, 2014; Tyler-Wood et al., 2012;). Importantly, the relationship between quantitative ability and STEM interest is relatively stable by middle school, develops concurrently thereafter through the undergraduate years, and is positively related to the likelihood of an individual to earn a degree in a STEM major (Le \& Robbins, 2016). Students who participate in expanded learning opportunities are also $20 \%$ less likely to drop out of school and $30 \%$ less likely to participate in 
Impact of the NE STEM 4U Intervention

criminal activities than peers who did not participate (Moeller \& Reitzes, 2011; Vandell, Reisner, \& Pierce, 2007). While studies among middle and high school students often demonstrate significant positive effects of out-of-school time (OST) STEM programs on youth interest in STEM, data about how similar programs impact elementary students' interest in STEM are lacking (Young, Ortiz, \& Young, 2017). Existing after-school programs that provide such opportunities to youth can utilize various pedagogical methods, such as inquiry-based learning (IBL), project-based learning, and peer-led team learning (Alexander, 2000). We incorporated problem-based learning to elementary youth in this intervention (Cutucache, Luhr, Nelson, Grandgenett, \& Tapprich, 2016).

In this study, we assessed the impact of the NE STEM 4U intervention on elementary school youth. Thus, our research question was: How does the NE STEM $4 U$ program influence the (a) excitement, (b) curiosity/inquiry, and (c) understanding of STEM concepts of elementary school participants? We used the Dimensions of Success (DoS) (Program in Education, Afterschool \& Resiliency (PEAR), 2015) tool to evaluate our questions and determine overall strengths and weaknesses of the NE STEM 4 U intervention for elementary school students.

\section{Methods}

\section{Participants}

Since it was founded in 2012 and first implemented in 2013, the NE STEM 4U program has reached between seven and 11 schools at the middle and elementary level, per semester. At the time of this writing the program has served approximately 8,000 youth. We work with citywide agencies, social workers, a state agency, and the school district administration to identify schools to participate in the program. Selection of schools is based upon low performance on Nebraska standardized assessments as well as high free and reduced lunch rates (Omaha Public Schools, 2014).

NE STEM 4U was initially focused on middle schools. However, in an effort to impact a broader range of age groups as they form their opinions about STEM, the program recently expanded to include a small subset of four elementary schools. This study focused on evaluating the program in these four elementary schools, with 114 participants (57.9\% males, $42.1 \%$ female) in grades K-6, from spring 2015 to spring 2016. All data were collected and analyzed under the IRB-approved protocol. Program participation among all schools is primarily composed of students in low income categories. These elementary schools meet the same selection criteria 


\section{Impact of the NE STEM 4U Intervention}

as middle schools. Moreover, each of the four elementary schools is part of the Nebraska $21^{\text {st }}$ Century Community Learning Centers $\left(21^{\text {st }} \mathrm{CCLC}\right)$, a program that supports expanded learning opportunities in schools with more than $40 \%$ low-income students (eligible for free/reduced lunch). The overall student body at the four participating sites is largely composed of minority groups where more than $88.8 \%$ of students qualify for free or reduced lunch (Table A1).

The NE STEM 4 U program serves students across K-16 by providing STEM learning opportunities for K-12 students, and teaching and mentorship experience for the undergraduate and graduate fellows who develop and deliver STEM learning lessons during each site visit. One high school mentor has participated as well, and that student subsequently attended University of Nebraska, Omaha and continued to work in the program. Mentors include both males and females of various ethnicities. Undergraduate and graduate mentors initially complete a facultysupervised orientation, training, and shadowing, and subsequently commit to providing a minimum of 3 hours per week of mentorship, lesson development, and teaching with the program. For each site visit included in this study, lessons were led by two to three mentors, except in one case where only one mentor was available.

\section{NE STEM $4 U$ Lessons}

NE STEM 4U lessons range in STEM topics including biology, chemistry, earth science, engineering, math and physics. Each activity has a corresponding lesson plan, which describes the procedures and learning objectives. Program mentors regularly (approximately once monthly) review and revise lesson plans based on feedback from evaluations such as the Dimensions of Success observations we present herein. Additionally, we have a curriculum leader and team of mentors that routinely edit lessons in collaboration with the University of Nebraska College of Education to ensure quality of lessons and feasibility to the elementary space. The lessons are designed to supplement and support the school day curricula. An example of a lesson plan for a chemistry lesson called "Exploring Gases" is shown in Figure 1.

The Dimensions of Success (DoS) observation tool is a method to evaluate the quality of STEM programs using objective measurements across a broad range of categories (PEAR, 2015). Each DoS observation report ranks the program in twelve specific areas among four general categories or domains, including Features of the Learning Environment, Activity Engagement, STEM Knowledge and Practices, and Youth Development in STEM (PEAR, 2014). The rubric allows for each of the twelve dimensions to score between a 1 (lowest) and 4 (highest). For this 
Impact of the NE STEM 4U Intervention

Figure 1. Example of a Problem-Based Learning Lesson Plan Utilized with Youth as Part of the NE STEM 4U Intervention

\begin{tabular}{|c|c|}
\hline Activity title & Exploring Gases \\
\hline Description & $\begin{array}{l}\text { This lesson includes a chemical reaction with baking soda and vinegar, as well } \\
\text { as a physical reaction with Diet Coke }{ }^{\circledR} \text { and } \text { Mentos }^{T M} \text {. }\end{array}$ \\
\hline Objectives & $\begin{array}{l}\text { To demonstrate the difference between a chemical reaction and physical } \\
\text { reaction. }\end{array}$ \\
\hline Materials & $\begin{array}{l}\text { Pop bottles, vinegar, baking soda, water, balloons, paper for funnels, diet cola, } \\
\text { club soda, mint Mentos }{ }^{\mathrm{TM}} \text {, a golf ball, and a clear cup. }\end{array}$ \\
\hline $\begin{array}{l}\text { Space } \\
\text { requirements }\end{array}$ & Classroom and outdoor area. \\
\hline Activity & $\begin{array}{l}\text { The group will take observations of a chemical reaction by mixing baking soda } \\
\text { with vinegar in a bottle topped with a balloon. They will observe the formation } \\
\text { of carbon dioxide as it fills the balloon up. Next, they will observe a physical } \\
\text { reaction by mixing Mentos }{ }^{\mathrm{M}} \text { with Diet Coke }{ }^{\circledR} \text {. The students will compare their } \\
\text { observations of the reactions and discuss the similarities and differences. }\end{array}$ \\
\hline Number of staff & $1-3$ \\
\hline Duration & 1 hour \\
\hline Ages/grade span & $\mathrm{K}-8$ grades \\
\hline Skills addressed & Scientific skills: taking observations, mixing chemicals together safely \\
\hline $\begin{array}{l}\text { Extensions } \\
\text { (if applicable) }\end{array}$ & Work cooperatively in a group, communicate effectively, set goals \\
\hline $\begin{array}{l}\text { Documentation \& } \\
\text { reflections }\end{array}$ & $\begin{array}{l}\text { The benefits of this lesson include performing scientific skills such as making } \\
\text { observations and forming hypotheses. This lesson is a fun way to show the } \\
\text { difference between chemical and physical reactions in a big picture way! }\end{array}$ \\
\hline
\end{tabular}

Template adapted from: The National Institute on Out-of-School Time and Wellesley Centers fore Women (2005).

study, an unbiased DoS-certified observer completely external to the project used the DoS observation tool to assign scores assessing the quality of programming of NE STEM 4U. Average scores were then computed by a researcher external to the program and assessment from spring 2015 to spring 2016. In addition to objective DoS scoring by an evaluator, youth voices are captured during the lesson as data sets as a component of the DoS tool. Specifically, the observer must use quotes from youth verbatim to assign a score within the 12 dimensions. Consequently, youth voice is then included in our data analysis using direct quotes from the 


\section{Impact of the NE STEM 4U Intervention}

participants. The authors used these comments as qualitative evidence of student gains resulting from the NE STEM 4 U intervention.

\section{Dimensions of Success Observation Tool}

The Dimensions of Success (DoS) observation tool is a method to evaluate the quality of STEM programs using objective measurements across a broad range of categories (PEAR, 2015). Each DoS observation report ranks the program in twelve specific areas among four general categories or domains, including Features of the Learning Environment, Activity Engagement, STEM Knowledge and Practices, and Youth Development in STEM (PEAR, 2014). The rubric allows for each of the twelve dimensions to score between a 1 (lowest) and 4 (highest). For this study, an unbiased DoS-certified observer completely external to the project used the DoS observation tool to assign scores assessing the quality of programming of NE STEM 4U. Average scores were then computed by a researcher external to the program and assessment from spring 2015 to spring 2016. In addition to objective DoS scoring by an evaluator, youth voices are captured during the lesson as data sets as a component of the DoS tool. Specifically, the observer must use quotes from youth verbatim to assign a score within the 12 dimensions. Consequently, youth voice is then included in our data analysis using direct quotes from the participants. The authors used these comments as qualitative evidence of student gains resulting from the NE STEM 4 U intervention.

\section{Results}

\section{Results of Classroom Observations using the Dimensions of Success Tool}

A total of nine observations of NE STEM 4 U lessons were conducted among four elementary schools from spring 2015 to spring 2016. Observation days and times were randomized in order to avoid bias from any particular lesson, instructor, or preparation time by instructor. Average DoS scores among observations were greater than or equal to 3 in all but one category, Relevance, which received an average score of 2.7. Scores were highest (greater than 3.5), on average, in five major categories, including Space Utilization, Relationships, Materials, Organization, and Youth Voice (Table 1). Further, observer comments on DoS evaluation sheets provided qualitative evidence of positive impacts of the NE STEM 4U program on elementary school students' excitement, curiosity/inquiry, and understanding of STEM concepts. 
Table 1. Average Dimensions of Success (DoS) Scores of Observations on a Scale of 1 (Lowest) to 4 (Highest), $(n=9)$

\begin{tabular}{|c|c|c|c|}
\hline \multirow[t]{2}{*}{ DoS Domain } & \multirow[t]{2}{*}{ Dos Category } & \multicolumn{2}{|c|}{ DoS Scores $(n=9)$} \\
\hline & & Average & Range \\
\hline \multirow[t]{3}{*}{ Features of the learning environment } & Organization & 3.6 & $3-4$ \\
\hline & Materials & 3.7 & $3-4$ \\
\hline & Space Utilization & 3.8 & $3-4$ \\
\hline \multirow[t]{3}{*}{ Activity engagment } & Participation & 3.4 & $3-4$ \\
\hline & Purposeful Activities & 3.4 & $3-4$ \\
\hline & Engagement with STEM & 3.4 & $3-4$ \\
\hline \multirow[t]{3}{*}{ STEM knowledge \& practices } & STEM Content Learning & 3.4 & $3-4$ \\
\hline & Inquiry & 3.0 & $2-4$ \\
\hline & Reflection & 3.0 & $2-4$ \\
\hline \multirow[t]{3}{*}{ Youth development in STEM } & Relationships & 3.8 & $3-4$ \\
\hline & Relevance & 2.7 & $1-4$ \\
\hline & Youth Voice & 3.6 & $3-4$ \\
\hline
\end{tabular}

\section{Influence of NE STEM 4U Program on Elementary Students' Perceptions}

Student excitement. The NE STEM $4 \mathrm{U}$ program is designed to get students excited about STEM topics. As part of this effort, mentors foster relationships with students, establish a comfortable learning environment, and encourage the participation and active engagement of each student involved. For example, upon first meeting a group of students, mentors introduce themselves to the students by first name and ask the students to introduce and share something about themselves, such as a favorite color. Mentors then reinforce this relationship during subsequent meetings by referring to each child by name and making sure that the students recall their names, too. This establishes a familiarity among the group. Notes from the DoS observation assessments suggest that students arrive excited and motivated to participate in the NE STEM $4 \mathrm{U}$ activities. For example:

- This was the first day of a new session. Many of these students had not been in a previous NE STEM 4U. They were all excited as they walked into the classroom. Once in the room, [the mentor] started with introduction of staff, "I'm in college, which is like, $17^{\text {th }}$ grade." The students loved hearing that. Each student was asked to give his or her 
Impact of the NE STEM 4 U Intervention

name, grade, and favorite subject. This was a great introduction to capture their attention and get focus on activity.

- It was apparent from the beginning that students felt comfortable and enjoyed being with [the mentors].

- When students arrived, they knew [Mentor's] name, and asked where [a mentor] was.

- Students had retained much of the information from previous activities, their favorite being the electrical current with the apples and bolts.

Under "Participation," observers often noted that students were actively engaging/participating in the activity, following directions, and completing the tasks. Additional observations indicated that students engaged in the hands-on activities and active exploration of STEM content, and that materials were "appealing and kept their attention." In two cases where the activity scored a 4 in the Relationship category, the evaluator noted that, "The students responded in a positive manner," and, "were listening and following directions while having the freedom to move around," regarding the interactions of the students with mentors.

Student curiosity/inquiry. In addition to increasing youth interest in science, the NE STEM 4U program seeks to encourage students to think critically and develop questions in preparation for or in response to the STEM topics to which they are exposed. DoS evaluations with scores of 3 or greater in the "Inquiry" category noted student inquiry in the form of making observations, asking questions, performing experiments, modeling peer sharing/feedback, and drawing conclusions, as evidenced by the examples listed below:

- During a Mentos ${ }^{\mathrm{TM}}$ and cola activity, students asked questions (e.g, "What if we added the whole package?"), carried out investigations, justified their hypothesis and shared their findings with each other.

- Making observations as they each tried to manipulate the arm model; asking questions as they were building the model; developing a model as they drew their design on the board; and sharing their findings with peers. At the conclusion of the class, [the mentor] asked each student to share what they learned. ...One student commented, "Our model could be used for other parts of our body like our legs. They both have muscles to help us move.

- As each student tried an experiment, the friends would give advice to help them be successful in the challenge.

Furthermore, an external assessment of our program (The PEAR Institute \& Institute for Measurement, Methodology, Analysis \& Policy, 2016) demonstrated that $78 \%$ of students reported that they had a more positive attitude about STEM because of their after-school 


\section{Impact of the NE STEM 4U Intervention}

experience, $73 \%$ had a STEM identity, and $80 \%$ indicated that their STEM career knowledge increased because of their after-school experience program. Additional specific highlights of our programming and impact on Nebraska's economy and expanding learning opportunities across Nebraska can be found in Cole, Sigmon, and Wishart (2017).

When any dimension received a rating of a 2 or less ( $n=6$ across all reports), evaluator comments noted weak evidence to support fulfillment of that category and/or strategies tending toward less authentic, cookbook, and/or staff-lead activities. For example:

- In the Inquiry category, a score of $2(n=2)$ yielded comments such as: "Students engaged in scientific practice, but in a more inauthentic manner. The activities were more of a cookbook nature that limited the student reasoning and thinking. They conducted the balloon/bottle experiment and made an observation, but it seemed the activities were [more] staff-led than students conducting authentic research practices"; and "The activity with building a new person was more of a step-by-step activity where staff was leading and students were following."

- In the Reflection category, scores of $2(n=2)$ yielded comments such as: "There was weak evidence that students were engaged in reflection," and, "[The mentors] would ask students questions to engage them in conversation, however, majority of students were paraphrasing or repeating what staff had just said."

- In the Relevance category, a score of $1(n=2)$ yielded comments such as: "There was not any evidence that the activities were made relevant beyond the activity itself."

Student understanding of STEM concepts. A main goal and critical part of the mission of NE STEM $4 \mathrm{U}$ is to increase understanding in STEM topics among socioeconomically disadvantaged students. Thus, we reviewed DoS evaluations for potential evidence suggesting that program activities promoted these learning gains. All DoS evaluations showed a score of 3 or higher in the category of STEM Content Learning. Further, examples taken from a broader range of categories, including Purposeful Activities, Reflection, Engagement with STEM, and Relevance also suggested increased student understanding of concepts related to the activity (Table 2). 
Impact of the NE STEM 4U Intervention

Table 2. Evaluator Observations Showing Evidence of STEM Concept Understanding

\begin{tabular}{|c|c|}
\hline DoS Category & Evidence of student understanding of STEM concepts \\
\hline \multirow[t]{3}{*}{$\begin{array}{l}\text { STEM } \\
\text { Content } \\
\text { Learning }\end{array}$} & $\begin{array}{l}\text { [The mentor], talking about muscles, asked students if they knew why it was called biceps. When he } \\
\text { related it to a bicycle ( } 2 \text { wheels), students were able to conclude, "So the muscle has two parts?" } \\
\text { Students also applied what they learned when drawing an arm model on the board. }\end{array}$ \\
\hline & $\begin{array}{l}\text { Mentor: "What would happen if we put a small piece of paper in the hole?" Student: "It will make more } \\
\text { friction. Maybe even so hot it will make a fire." }\end{array}$ \\
\hline & $\begin{array}{l}\text { When asked where the nucleus of the cell was, one student answered, "It can't be outside the cell } \\
\text { because it acts as its brain and powers the cell." }\end{array}$ \\
\hline \multirow[t]{3}{*}{$\begin{array}{l}\text { Purposeful } \\
\text { Activities }\end{array}$} & $\begin{array}{l}\text { (The mentor drew a model DNA on the board.) Mentor: "Who can tell me what this is?" Several } \\
\text { students gave answers, however one young man said, "It's the thing in your body that tells it what to } \\
\text { do." [The mentor] built upon that answer to explain the role of DNA in our bodies and how it } \\
\text { determines certain traits. }\end{array}$ \\
\hline & $\begin{array}{l}\text { Example of how students applied knowledge: [the mentor] was showing his group how the muscle } \\
\text { (balloon) stretched when you pull your arm up. As a student was conducting the experiment, the } \\
\text { balloon popped. Another student said, "That's what happened to my dad. He was lifting something } \\
\text { heavy and his muscle popped." }\end{array}$ \\
\hline & $\begin{array}{l}\text { Mentor: "What do you know about friction?" Student: "It's what slows things down." Students were } \\
\text { able to apply what they learned, for example, Mentor: "What happens when you rub your hands } \\
\text { together?" Students: "They get hot." Mentor: "What do we call that?" Students: "Friction." }\end{array}$ \\
\hline \multirow[t]{5}{*}{ Reflection } & $\begin{array}{l}\text { [The mentor] asked, "What happens when you cover your mouth?" "What then happens if you don't } \\
\text { get any air?" Students were able to apply the knowledge of air being important to the lungs; expand, } \\
\text { contracting when they take in air. }\end{array}$ \\
\hline & $\begin{array}{l}\text { Mentor: "Think about your tiny little hole in your microscope. What could you see?" Student: "When I } \\
\text { looked at things, they got bigger." }\end{array}$ \\
\hline & $\begin{array}{l}\text { When discussing the lysosomes, (blue shark candy) she said "think about what a shark might do if it } \\
\text { lived in your cell?" One student mentioned, "It would eat it up." [The mentor] "Exactly, so the job of } \\
\text { the shark (lysosome) is to eat the bacteria in the cell." }\end{array}$ \\
\hline & $\begin{array}{l}\text { Following the balloon/bottle experiment, [the mentor] asked students, "Whose balloon is the largest? } \\
\text { What made one balloon blow up more than someone else's?" One student replied, "He added more } \\
\text { baking soda?" She then asked, "What else could have caused his to get bigger?" Another student } \\
\text { answered, "The water level, it's stronger." }\end{array}$ \\
\hline & $\begin{array}{l}\text { As they left, [the mentor] asked them to say one thing they learned today. Majority of students were } \\
\text { able to list something related to the activities. }\end{array}$ \\
\hline
\end{tabular}


Impact of the NE STEM $4 \mathrm{U}$ Intervention

Table 2. (Cont.)

\begin{tabular}{|l|l|}
\hline DoS Category & Evidence of student understanding of STEM concepts \\
\hline Engagement & $\begin{array}{l}\text { Mentor: "If you can name an organ, then you can name a cell. Like heart cells, lung cells, } \\
\text { etcetera....Does anyone know how we go from cell to organism?" Student: "If you bunch cells you } \\
\text { get tissues and then an organ and finally an organism." }\end{array}$ \\
\hline & $\begin{array}{l}\text { (Following the balloon/bottle experiment) Mentor: "So what happened when we tipped the baking } \\
\text { soda into the vinegar solution?" Student: "The baking soda made my solution blow up the balloon." } \\
\text { Mentor: "What did it create?" [(same) Student]: "We made a gas that blew up the balloon." }\end{array}$ \\
\hline $\begin{array}{l}\text { [The mentor], talking about muscles, asked students if they knew why it was called biceps. When he } \\
\text { related it to a bicycle (2 wheels), students were able to conclude, "So the muscle has two parts?" } \\
\text { Students also applied what they learned when drawing an arm model on the board. }\end{array}$ & $\begin{array}{l}\text { Students were able to become actively engaged with their minds as they tried each of the } \\
\text { experiments. This was evident in the heat conversion activity, when [the mentor] asked, "We talked } \\
\text { about how friction causes heat. How do we know?" Students answered, "It gets hot." He followed up } \\
\text { with, "How do we measure that heat?" They answered, "A thermometer." }\end{array}$ \\
\hline Mentor: "What can we use a microscope for?" Student: "To look at germs that make us sick."
\end{tabular}

\section{Discussion}

This article describes the evaluation of the quality and impact of the NE STEM 4U intervention on youth in elementary school grades. Specifically, this study focused on the following research question: How does the NE STEM 4U program influence the (a) excitement, (b) curiosity/inquiry, and (c) understanding of STEM concepts of elementary school participants?

From this study, and the quantitative DoS data, we observed that the NE STEM 4U program within elementary schools was most effective in Space Utilization, Relationships, Materials, Organization, and Youth Voice (average scores greater than 3.5). Scores were high (greater than 3) across most categories. The weakest observation category was Relevance, though it still received an overall average score of 2.7. Supportive qualitative examples justifying the impact of the NE STEM $4 \mathrm{U}$ intervention on excitement, curiosity/inquiry, and understanding of STEM concepts are illustrated in Table 2. One of the major limitations we identified, as previously mentioned in the methods section, is that the instructor can influence student learning outcomes and interest, even when learning objectives, lesson plan, prior training, and delivery of information are all normalized. Similarly, students may identify with a mentor of a particular age, race, or gender more than another, thus influencing their engagement in the program. We 


\section{Impact of the NE STEM 4U Intervention}

cannot account for these preferences, nor any differences in instructor charisma or other personality traits, but these are partly mitigated by the fact that mentoring is done in teams of mentors.

These results emphasize that NE STEM $4 \mathrm{U}$ is a highly effective STEM learning model for elementary school students, which maximizes the learning environment with smooth delivery of STEM learning activities and use of appropriate materials to enhance engagement and understanding of STEM concepts. Further, undergraduate and graduate mentors build rapport with students via one-on-one interactions, thus encouraging them to share their perspectives and make meaningful scientific decisions. Importantly, this intervention has led to improved curiosity, inquiry, and scientific thinking among youth in elementary schools. Sustained partnerships and high quality after-school programs help to build and maintain the STEM pipeline. The NE STEM $4 \mathrm{U}$ program serves as a model for other metropolitan universities to recruit youth into the STEM pipeline by raising STEM awareness and curiosity during a highly influential time in their development.

\section{Acknowledgements}

Thanks to the Nebraska Children's Learning Center Network and Beyond School Bells, particularly Jeff Cole and Julie Sigmon, for assisting in DoS training opportunities for our staff. The authors acknowledge The Sherwood Foundation (C.C., N.G., and W.T.), Nebraska Research Initiatives (W.T. and C.C.), and the Nebraska University Foundation (C.C.) for funding of this project. Thanks to Collective for Youth staff for helping to make these opportunities possible to youth at a citywide level, as well as providing ongoing counseling and training opportunities to our staff. Thanks especially to Megan Addison, Gwyn Williams, and Nicole Everingham. Thanks also to all youth participants, the Omaha Public Schools after-school site directors, and the administrative leadership at Omaha Public Schools, including Dr. Chris Schaben. The authors declare no conflict of interest.

\section{References:}

Alexander, D. (2000). The learning that lies between play and academics in after-school programs. National Institute on Out-of-School Time, Wellesley Centers for Women. Retrieved from https://www.niost.org/pdf/learning_article.pdf 
Impact of the NE STEM 4U Intervention

Avanzato R. (2000). Mobile robotics for freshman design, research, and high school outreach. Proceedings of the 2000 IEEE International Conference on Systems, Man and Cybernetics. 1, 736-739. doi: 10.1109/ICSMC.2000.885083

Carpenter, S. (2015). Undergraduates' perceived gains and ideas about teaching and learning science from participating in science education outreach programs. Journal of Higher Education Outreach and Engagement, 19(3), 113-146.

Chng, E., Yew E. H., Schmidt, H. G. (2011, October). Effects of tutor-related behaviours on the process of problem-based learning. Advances in Health Sciences Education: Theory and Practice, 16(4), 491-503. doi: 10.1007/s10459-011-9282-7

Constan, Z., \& Spicer, J. (2015). Maximizing future potential in physics and STEM: Evaluating a summer program through a partnership between science outreach and education research. Journal of Higher Education Outreach and Engagement, 19(2), 117-136.

Cole, J., Sigmon, J., Wishart, A. (2017). The Nebraska way: Building STEM learning systems from the bottom up. Retrieved May 2, 2017 from Stem Ready America website: http://stemreadyamerica.org/article-nebraska-way/

Cusick, A. (2001). Australian occupational therapy, evidence based practice and the $21^{\text {st }}$ century. Australian Occupational Therapy Journal, 48, 102-117.

Cutucache, C.E., Luhr, J.L., Nelson, K.L., Grandgenett, N., Tapprich, W.E. (2016). NE STEM 4U: An outof-school time academic program to improve achievement of socioeconomically disadvantaged youth in STEM areas. International Journal of STEM Education, 3(6), 1-7.

Dabney, K .P., Tai, R. H., Almarode, J. T., Miller-Friedmann, J. L., Sonnert, G., Sadler, P. M., \& Hazari, Z. (2011). Out-of-school time science activities and their association with career interest in STEM. International Journal of Science Education, Part B. doi: 10.1080/21548455.2011.629455

Desilver, D. (2017). U.S. students' academic achievement still lags that of their peers in many other countries. Retrieved May 19, 2017 from Pew Research Center website: http://www.pewresearch.org/fact-tank/2017/02/15/u-s-students-internationally-math-science/

Duran, M., Höft, M., Lawson, D. B., Medjahed, B., \& Orady, E. A. (2014). Urban high school students' IT/STEM learning: Findings from a collaborative inquiry- and design-based afterschool program. Journal of Science Education and Technology, 23, 116-137.

Greater Omaha Chamber of Commerce and AIM/Careerlink. (2015). Tech talent growth. Retrieved from http://omahachamber.org/pdf/Tech\%20Talent\%20Strategy.pdf

Husain A. (2011). Problem-based learning: a current model of education. Oman Medical Journal, 26, 295.

Imans, D. H., Wilkerson L. (2011). Reflection on studies on the learning process in problem-based learning. Advances in Health Sciences Education: Theory and Practice, 16, 437-41.

Klegeris, A. \& Hurren, H. (2011). Impact of problem-based learning in a large classroom setting: Student perception and problem-solving skills. Advances in Physiology Education, 35, 408-15. 
Lauer, P. A., Akiba, M., Wilkerson, S. B., Apthorp, H. S., Snow, D., \& Martin-Glenn, M. L. (2006). Out-ofschool time programs: A meta-analysis of effects for at-risk students. Review of Educational Research, 76, 275-313.

Le, H. \& Robbins, S. B. (2016). Building the STEM pipeline: Findings of a 9-year longitudinal research project. Journal of Vocational Behavior, 95-96, 21-30.

Lira, A. L. \& Lopes, M. V. (2011). Nursing diagnosis: educational strategy based on problem-based learning. Revista Latino-Americana de Enfermagem, 19, 936-43.

Maltese, A. V., \& Tai, R. H. (2010). Eyeballs in the fridge: Sources of early interest in science. International Journal of Science Education, 32, 669-685.

Miller, B. M. (2003). Critical hours: Afterschool programs and educational success. Retrieved from Nellie Mae Education Foundation website: https://www.nmefoundation.org/getmedia/08b6e87b-69ff4865-b44e-ad42f2596381/Critical-Hours?ext=.pdf

Moeller, B., \& Reitzes, T. (2011). Integrating technology with student-centered learning. Quincy, MA: Nellie Mae Education Foundation.

Moreno, N. P., Tharp, B. Z., Vogt, G., Newell, A. D., \& Burnett, C. A. (2016). Preparing students for middle school through after-school STEM activities. Journal of Science Education and Technology, 25, 889-897. doi: 10.1007/s10956-016-9643-3

National Institute on Out-of-School Time, Wellesley Centers for Women. (2005). Links to learning: $A$ curriculum planning guide for after-school programs. Nashville, TN: School Age Notes.

Nebraska Department of Education. (2014). 2014-15 Free and reduced lunch counts by school [Data File]. Retrieved from http://drs.education.ne.gov/quickfacts/Pages/StudentCharacteristics.aspx Nebraska Department of Education. (2015a). 2015-16 Free and reduced lunch counts by schoo/ [Data File]. Retrieved from http://drs.education.ne.gov/quickfacts/Pages/StudentCharacteristics.aspx Nebraska Department of Education. (2015b). 2014-2015 Data, research and evaluation: Membership by grade, race and gender [Data File]. Retrieved from http://drs.education.ne.gov/quickfacts/Pages/StudentCharacteristics.aspx

Nebraska Department of Education. (2015c). 2015-2016 Data, research and evaluation: Membership by grade, race and gender [Data File]. Retrieved from http://drs.education.ne.gov/quickfacts/Pages/StudentCharacteristics.aspx

Nicholl, T. A. \& Lou, K. (2012). Aug 10. A model for small-group problem-based learning in a large class facilitated by one instructor. American Journal of Pharmaceutical Education 76(6). doi: 10.5688/ajpe766117

Okubo Y, Ishiguro N, Suganuma T, Nishikawa T, Takubo T, Kojimahara N, ...\& Yoshioka, T. (2012). Team-based learning, a learning strategy for clinical reasoning, in students with problem-based learning tutorial experiences. Tohoku Journal of Experimental Medicine, 2271), 23-29. 
Journal of Youth Development | http://jyd.pitt.edu/ | Vol. 12 Issue 2 DOI 10.5195/jyd.2017.474

Impact of the NE STEM 4U Intervention

Omaha Public Schools. (2014). Research [quick facts and reports]. Retrieved from http://district.ops.org/DEPARTMENTS/GeneralFinanceandAdministrativeServices/Research.aspx

The PEAR Institute: Partnerships in Education and Resilience \& Institute for Measurement, Methodology, Analysis \& Policy. (2016). Afterschool learning is a powerful STEM solution. Retrieved May 17, 2017 from http://ccc.nlc.org/files/2017/01/APAN-STEM-Evaluation-Overview.pdf

Program in Education, Afterschool \& Resiliency. (2014). An introductory guide to the Dimensions of Success (DoS) Observation tool. Retrieved from http://www.pearweb.org/tools/flyers/DoSGuide_ForOrganizations_2014.pdf

Program in Education, Afterschool \& Resiliency. (2015). Dimensions of success. Retrieved from http://www.pearweb.org/tools/dos.html

President's Council of Advisors on Science and Technology (PCAST). (2010). Report to the President: Prepare and inspire: $K-12$ education in science, technology, engineering, and math (STEM) for America's future. Retrieved from http://www.whitehouse.gov/sites/default/files/microsites/ostp/pcast-stemed-report.pdf

Salinitri F. D., O'Connell M. B., Garwood, C. L., Lehr, V. T., \& Abdallah K. (2012). Apr 10. An objective structured clinical examination to assess problem-based learning. American Journal of Pharmaceutical Education, 76(3), 44. doi: 10.5688/ajpe76344

Schnittka, C. G., Evans, M. A., Won, S., \& Drape, T. D. (2016). After-school spaces: Looking for learning in all the right places. Research in Science Education, 46(3), 389-412. doi: 10.1007/s11165-0159463-0

Tai R., Liu, C. Q., Maltese A. V., \& Fan, X. T. (2006). Planning for early careers in science. Science, 312(5777), 1143-1144.

Teaching Institute for Excellence in STEM. (2016, May). STEM Funders Network announces 10 new U.S. ecosystems to the STEM Learning Ecosystems Initiative. Announced at the 2016 U.S. News STEM Solutions National Leadership Conference. Retrieved from http://www.tiesteach.org/assets/content/assets/uploads/TIES_10_New_STEM_Ecosystems_Anno unced_-_5-19-16.pdf

Tyler-Wood, T., Ellison, A., Lim, O., \& Periathiruvadi, S. (2012). Bringing up girls in science (BUGS): The effectiveness of an afterschool environmental science program for increasing female students' interest in science careers. Journal of Science Education and Technology, 21(1), 46-55. doi: 10.1007/s10956-011-9279-2

Vandell, D. L., Reisner, E. R., \& Pierce, K. M. (2007). Outcomes linked to high-quality afterschool programs: Longitudinal findings from the Study of Promising Afterschool Programs. Irvine: University of California, Madison: University of Wisconsin; Washington, DC: Policy Studies Associates, Inc. 
Journal of Youth Development ｜ http://jyd.pitt.edu/ | Vol. 12 Issue 2 DOI 10.5195/jyd.2017.474 Impact of the NE STEM 4U Intervention

Wiznia, D., Korom, R., Marzuk, P., Safdieh, J., \& Grafstein, B. (2012). PBL 2.0: enhancing problem-based learning through increased student participation. Medical Education Online, 17, doi: 10.3402/meo.v17i0.17375

Young, J. R., Ortiz, N. A., \& Young, J. L. (2017). STEMulating interest: A meta-analysis of the effects of out-of-school time on student STEM interest. International Journal of Education in Mathematics, Science and Technology, 5(1), 62-74. doi:10.18404/ijemst.61149 
Journal of Youth Development | http://jyd.pitt.edu/ | Vol. 12 Issue 2 DOI 10.5195/jyd.2017.474

Impact of the NE STEM 4U Intervention

\section{Appendix}

Table A1. Demographic Data of Students in Four Schools Where NE STEM 4 U Activities were Conducted from Spring 2015 to Spring 2016

\begin{tabular}{|c|c|c|c|c|c|c|c|c|c|}
\hline \multirow[t]{2}{*}{ Year } & \multirow[t]{2}{*}{ Site } & \multicolumn{7}{|c|}{ Ethnicities } & \multirow{2}{*}{$\begin{array}{c}\text { Free/ } \\
\text { Reduced } \\
\text { Lunch }\end{array}$} \\
\hline & & White & Black & Hispanic & Asian & AI/IN* & NHPI* & $\begin{array}{c}\geq 2 \\
\text { Races }\end{array}$ & \\
\hline \multirow{4}{*}{$\begin{array}{l}2014- \\
15\end{array}$} & 1 & $4.6 \%$ & $4.2 \%$ & $84.1 \%$ & $4.6 \%$ & $1.3 \%$ & $0.0 \%$ & $1.3 \%$ & $97.49 \%$ \\
\hline & 2 & $16.9 \%$ & $64.7 \%$ & $8.4 \%$ & $1.2 \%$ & $0.5 \%$ & $0.0 \%$ & $8.4 \%$ & $93.27 \%$ \\
\hline & 3 & $40.8 \%$ & $2.7 \%$ & $51.6 \%$ & $1.3 \%$ & $0.9 \%$ & $0.0 \%$ & $2.7 \%$ & $94.17 \%$ \\
\hline & 4 & $10.0 \%$ & $66.2 \%$ & $13.1 \%$ & $4.0 \%$ & $0.7 \%$ & $0.5 \%$ & $5.6 \%$ & $88.81 \%$ \\
\hline \multirow{4}{*}{$\begin{array}{l}2015- \\
16\end{array}$} & 1 & $8.3 \%$ & $4.4 \%$ & $82.5 \%$ & $3.4 \%$ & $0.0 \%$ & $0.0 \%$ & $1.5 \%$ & $93.20 \%$ \\
\hline & 2 & $15.3 \%$ & $62.4 \%$ & $11.3 \%$ & $1.5 \%$ & $0.9 \%$ & $0.0 \%$ & $8.6 \%$ & $93.36 \%$ \\
\hline & 3 & $35.2 \%$ & $3.0 \%$ & $54.8 \%$ & $1.3 \%$ & $0.9 \%$ & $0.0 \%$ & $4.8 \%$ & $93.04 \%$ \\
\hline & 4 & $45.0 \%$ & $28.5 \%$ & $12.1 \%$ & $3.9 \%$ & $0.6 \%$ & $0.1 \%$ & $9.7 \%$ & $89.78 \%$ \\
\hline
\end{tabular}

*AI/IN = American Indian/Alaska Native; NHPI = Native Hawaiian/Pacific Islander

Compiled from Nebraska Department of Education (2014, 2015a-c). Accessed December 22, 2016. 